\title{
A Study on the Activation of Carbide Slag Cementitious Materials
}

\author{
Mingyue $\mathrm{Wu}$ \\ Key Lab of Mine Disaster Prevention \\ and Control \\ College of Mining and Safety \\ Engineering \\ Shandong University of Science and \\ Technology \\ Qingdao, China \\ Mywu1212@163.com \\ Weimin Cheng \\ Key Lab of Mine Disaster Prevention \\ and Control \\ College of Mining and Safety \\ Engineering \\ Shandong University of Science and \\ Technology \\ Qingdao, China \\ chengmw@163.com
}

\author{
Xiangming $\mathrm{Hu}$ \\ Key Lab of Mine Disaster Prevention \\ and Control \\ College of Mining and Safety \\ Engineering \\ Shandong University of Science and \\ Technology \\ Qingdao, China \\ xiangming0727@163.com \\ Lin Xin \\ Key Lab of Mine Disaster Prevention \\ and Control \\ College of Mining and Safety \\ Engineering \\ Shandong University of Science and \\ Technology \\ Qingdao, China \\ xinlinsdust@163.com
}

\author{
Qian Zhang \\ Key Lab of Mine Disaster Prevention \\ and Control \\ College of Mining and Safety \\ Engineering \\ Shandong University of Science and \\ Technology \\ Qingdao, China \\ 528243891@qq.com \\ Yanyun Zhao \\ College of Chemical and \\ Environmental Engineering \\ Shandong University of Science and \\ Technology \\ Qingdao, China \\ 7407269@qq.com
}

\begin{abstract}
This research used orthogonal testing methods to study the effect of stimulator content on the properties of carbide slag (CS) cementitious materials. Range and variance analyses reveal that different stimulators do not significantly affect the consistencies and setting times of these cementitious materials, but influenced considerably their flexural and compressive strengths; the influence decreases in the order: $\mathrm{NaOH}>\mathrm{CaCl}_{2}>\mathrm{Na}_{2} \mathrm{SO}_{4}>\mathrm{Na}_{2} \mathrm{SiO}_{3}$. Further analyses show that the strengths of these cementitious materials increase with increasing $\mathrm{NaOH}$ content, and decrease with increasing $\mathrm{CaCl}_{2}$ content. When the mass ratio of $\mathrm{Na}_{2} \mathrm{SO}_{4}: \mathrm{Na}_{2} \mathrm{SiO}_{3}: \mathrm{CaCl}_{2}$ : $\mathrm{NaOH}$ was 1: 1: 0: 5, the stimulators exhibited the best activating effect. X-ray diffraction (XRD) and Scanning electron microscope (SEM) analyses showed that the 28-day hydration products contain large amounts of ettringite (AFt), calcium silicate hydrate (C-S-H), calcium aluminate hydrate (C-A-H), and small amounts of unreacted $\mathrm{Ca}(\mathrm{OH})_{2}$ and quartz. These hydration products increased the strengths of these cementitious systems.
\end{abstract}

Keywords-filling material, orthogonal testing, hydration mechanism, microscopic analysis

\section{INTRODUCTION}

Mining activities bring us resources, as well as geological hazards and environmental pollution, most prominently in the form of surface subsidence. Cement filling is an effective technique to avoid or reduce surface subsidence. Cementitious materials prepared from industrial waste, such fly ash (FA), are frequently used for this purpose. This filling method offers new ways of utilizing waste, and effectively promotes the sustainable development of the coal industry. Chen et al. [1] used FA as a feedstock for the development of a cementitious material that meets filling requirements, but the addition of cement clinker resulted in increased costs. Therefore, the key to the successful implementation of cemented filling is the identification of a high-quality and economical cementitious material.

$\mathrm{CS}$ is the waste from the hydrolysis of calcium carbide used in the formation of acetylene gas, with $\mathrm{CaO}$ and $\mathrm{Ca}(\mathrm{OH})_{2}$ as its main components. The main reaction for its formation is: $\mathrm{CaC}_{2}+2 \mathrm{H}_{2} \mathrm{O} \rightarrow \mathrm{C}_{2} \mathrm{H}_{2} \uparrow+\mathrm{Ca}(\mathrm{OH})_{2}$ [2]. As industry develops, the production of $\mathrm{CS}$ increases every year. These large quantities of CS, if untreated, produce irritating odors and atmospheric pollution. The long-term accumulation of CS consumes large areas of land, and also has a severe corrosive effect on soil. In addition, by entering the water system, CS can also clog rivers [3-5]. FA is the fine ash collected from the burning of coal. It can be activated under alkaline conditions to produce a material similar to volcano ash [6]. Blast-furnace-slag (BFS) is formed by the cooling of molten-iron slag by water and has water-binding potential. Flue-gas desulfurization gypsum (FGD gypsum) is the industrial by-product produced during the recollection of $\mathrm{SO}_{2}$ from coal burning or oil fumes by lime or limestone, with its main component being $\mathrm{CaSO}_{4} \cdot 2 \mathrm{H}_{2} \mathrm{O}$. Over the years, China has invested heavily in solving these waste problems, with few satisfactory results to date. The effective utilization of this solid industrial waste is an issue of serious concern in China.

Domestic and foreign scientists have contributed strongly to the utilization of industrial solid waste and have achieved some important results. Horpibulsk et al. [7,8] compared the strengths and microstructures of CS, cement, and FA-stabilized silt and found that the strengths of the CS 
and FA-stabilized silt improved with increased curing time. Fan et al. [2] used CS as the main material for the preparation of aerated concrete, which exhibited a compressive strength of $2 \mathrm{MPa}$. Yi et al. [9] used CS to activate BFS during the preparation of soft clay, and found that a CS content of $4 \%-6 \%$ gave the best soft-clay stability. Hao et al. [10] studied the influence of CS and FA on the compressive strength of a mixed cement paste through surface modification. It should be noted that in these studies cement clinker was added to the CS, FA or $\mathrm{BFS}$, resulting in less-economical processes.

FA and BFS can generate water-binding materials in alkaline environments. The alkaline stimulants commonly used are: $\mathrm{NaOH}, \mathrm{Na}_{2} \mathrm{SiO}_{3}$, and $\mathrm{Na}_{2} \mathrm{SO}_{4}$, among others. Guo et al. [11] used $\mathrm{NaOH}$ and $\mathrm{Na}_{2} \mathrm{SiO}_{3}$ to activate FA for the preparation of a composite binder, with a maximum compressive strength $80.0 \mathrm{MPa}$ achieved. Pavel et al. $\left[12^{]}\right.$ prepared a geopolymer by activating FA in an alkaline environment. Nematollahi et al. [13] studied the preparation of a geopolymer by the joint activation of FA with $\mathrm{Na}_{2} \mathrm{SiO}_{3}$ and $\mathrm{NaOH}$, and found that the best performance of the polymer was achieved at $\mathrm{Na}_{2} \mathrm{SiO}_{3} / \mathrm{NaOH}=2.5$. Criado et al. [14] studied the stimulation of $\mathrm{FA}$ by $\mathrm{Na}_{2} \mathrm{SO}_{4}$ in an alkaline environment, and found that the level of activation was affected to a large extent by the $\mathrm{NaOH}$ in the system, but did not offer an explanation. Yi et al. [15] studied the joint activation of BFS by $\mathrm{CS}, \mathrm{NaOH}, \mathrm{Na}_{2} \mathrm{CO}_{3}$ and $\mathrm{Na}_{2} \mathrm{SiO}_{3}$, and found that $\mathrm{Na}_{2} \mathrm{SiO}_{3}$ was most effective, while $\mathrm{Na}_{2} \mathrm{CO}_{3}$ was least effective. Marjanovi et al. [16] used $\mathrm{Na}_{2} \mathrm{SiO}_{3}$ and $\mathrm{NaOH}$ to activate FA and BFS, and found that the best activation was achieved when the mass ratio of alkali activators $\left(\mathrm{SiO}_{2} / \mathrm{Na}_{2} \mathrm{O}\right)$ was 1.0 , at a concentration of $10 \%$. Zhang et al. [17] studied the influence of $\mathrm{NaOH}, \mathrm{CaCl}_{2}$, $\mathrm{Na}_{2} \mathrm{SO}_{4}$ and $\mathrm{K}_{2} \mathrm{SO}_{4}$ on the strength of FA-BFS cement using orthogonal testing, and found that combining the four stimulants had a positive effect on the strength of the cement. The effect of the stimulant was found to decrease in the order: $\mathrm{Na}_{2} \mathrm{SO}_{4}>\mathrm{NaOH}>\mathrm{CaCl}_{2}>\mathrm{K}_{2} \mathrm{SO}_{4}$, but the authors did not suggest a mechanism for this observation. The above studies indicate that $\mathrm{Na}_{2} \mathrm{SO}_{4}, \mathrm{Na}_{2} \mathrm{SiO}_{3}, \mathrm{CaCl}_{2}$ and $\mathrm{NaOH}$ can effectively activate FA and BFS. However, little attention has been given to the addition of specific amounts of CS to $\mathrm{Na}_{2} \mathrm{SO}_{4}, \mathrm{CaCl}_{2}, \mathrm{Na}_{2} \mathrm{SiO}_{3}$ and $\mathrm{NaOH}$ in order to form an alkaline activating system that can be used on FA and BFS. The addition of CS serves to provide calcium to the cementitious system, as well as promoting the formation of $\mathrm{OH}^{-}$, which aids in the fragmentation of the acidic membranes on the FA and BFS-particle surfaces. With the continual consumption of $\mathrm{Ca}^{2+}$, and the reaction of $\mathrm{Na}^{+}$ (from $\mathrm{Na}_{2} \mathrm{SiO}_{3}$ and $\mathrm{Na}_{2} \mathrm{SO}_{4}$ ) in the presence of $\mathrm{OH}^{-}$, the dissolution of $\mathrm{Ca}(\mathrm{OH})_{2}$ in the $\mathrm{CS}$ was further enhanced. Theoretical analysis shows that this use of solid waste, such as CS, as the raw material for the preparation of filling materials for green mining applications, is feasible. The identification of the optimum proportions of $\mathrm{Na}_{2} \mathrm{SO}_{4}$, $\mathrm{Na}_{2} \mathrm{SiO}_{3}, \mathrm{CaCl}_{2}$ and $\mathrm{NaOH}$, to best activate FA and BFS, and to improve the performance of cementitious material, is a current topic of discussion.

Based on the above discussion, we studied the activation of FA and BFS using CS with $\mathrm{Na}_{2} \mathrm{SO}_{4}, \mathrm{Na}_{2} \mathrm{SiO}_{3}, \mathrm{CaCl}_{2}$ and $\mathrm{NaOH}$, without the addition of cement clinker, and determined the best ratio of stimulants by range and variance analyses. This paper also investigated the performance and hydration mechanisms of cementitious materials, and analyzed the composition of hydration products and their microstructures using XRD and SEM. The proposed method for the preparation of mine filling materials has the potential to consume large quantities of industrial waste such as CS, FA and BFS, and benefits the preparation and promotion of high-quality and low-cost mine filling materials.

\section{EXPERIMENTAL}

\section{A. Raw Materials}

CS was purchased from the Acetylene Gas Plant, Linzi, Shandong. FA, BFS, and FGD gypsum were purchased from the Shanshui Cement Co. Ltd., Binzhou, Shandong. Anhydrous $\mathrm{CaCl}_{2}(\geq 96.0 \%)$, anhydrous $\mathrm{Na}_{2} \mathrm{SO}_{4}(\geq 99.0 \%$ and $\mathrm{Na}_{2} \mathrm{O} / \mathrm{SiO}_{2}=1.03 \pm 0.03$ ) and $\mathrm{NaOH}(\geq 96.0 \%$ ), as stimulators, were purchased from Kaitong Chemical Reagents Co. Ltd., Tianjin. Naphthalene-based superplasticizer (chloride $<0.4 \%$, sulfa $<9 \%$, solid content $\geq 93 \%$ ) was purchased from Chenqi Chemical Technology Co. Ltd., Shanghai.

Preparation of raw materials:

The CS was calcined at $1000{ }^{\circ} \mathrm{C}$ for $30 \mathrm{~min}$. It contained $64.57 \% \mathrm{CaO}$ and $25.19 \% \mathrm{Ca}(\mathrm{OH})_{2}$, with a density of $2.64 \mathrm{~g} / \mathrm{cm}^{3}$ and a specific surface area of $419 \mathrm{~m}^{2} / \mathrm{kg}$. The chemical composition of this material is listed in Table 1, and the corresponding X-ray diffraction (XRD) pattern is depicted in Fig. 1a.

The FA had a density of $1.78 \mathrm{~g} / \mathrm{cm}^{3}$ and a specific surface area $219 \mathrm{~m}^{2} / \mathrm{kg}$. The chemical composition of this material is listed in Table 1, and the corresponding X-ray diffraction (XRD) pattern is depicted in Fig. 1b.

The BFS had a density of $2.88 \mathrm{~g} / \mathrm{cm}^{3}$ and a specific surface area of $361 \mathrm{~m}^{2} / \mathrm{kg}$. The chemical composition of this material is listed in Table 1 , and the corresponding X-ray diffraction (XRD) pattern is depicted in Fig. 1c.

The FGD gypsum contained $>90 \% \mathrm{CaSO}_{4} \cdot 2 \mathrm{H}_{2} \mathrm{O}$ and was calcined at $180{ }^{\circ} \mathrm{C}$ for $2 \mathrm{~h}$ in order to change its main component to semi-hydrated $\beta$-gypsum, with a density of $2.64 \mathrm{~g} / \mathrm{cm}^{3}$ and a specific surface area of $269 \mathrm{~m}^{2} / \mathrm{kg}$, and the corresponding X-ray diffraction (XRD) pattern is depicted in Fig. 1d.

The river sand used was round silica sand containing no less than $98 \% \mathrm{SiO}_{2}$. The particle size distribution is listed in Table 2. Tap water was used for all experiments.

TABLE 1. CHEMICAL COMPOSITIONS OF RAW MATERIALS (wt\%).

\begin{tabular}{cccc}
\hline Raw materials & $\boldsymbol{F A}$ & $\boldsymbol{C S}$ & $\boldsymbol{B F S}$ \\
\hline $\mathbf{L o s s}$ & 4.22 & 1.7 & 0.25 \\
$\mathrm{SiO}_{2}$ & 45.98 & 3.16 & 30.13 \\
$\mathrm{Al}_{2} \boldsymbol{O}_{3}$ & 31.79 & 2.72 & 17.14 \\
$\mathrm{Fe}_{2} \boldsymbol{O}_{3}$ & 6.18 & 0.42 & 0.71 \\
$\mathbf{C a O}$ & 3.67 & 64.57 & 38.83 \\
$\mathbf{M g O}$ & 0.90 & 0.72 & 7.38 \\
$\mathbf{S O}_{2}$ & 0.70 & 1.52 & 0.59 \\
$\mathbf{C a}(\boldsymbol{O H})_{2}$ & - & 25.19 & - \\
\hline
\end{tabular}

TABLE 2. SAND PARTICAL SIZE DISTRIBUTION

\begin{tabular}{cccc}
\hline $\begin{array}{c}\text { Particle } \\
\text { size }(\boldsymbol{m m})\end{array}$ & Percentage $(\%)$ & $\begin{array}{c}\text { Particle size } \\
(\mathbf{m m})\end{array}$ & Percentage $(\%)$ \\
\hline 2.0 & 0 & 0.5 & $67 \pm 5$ \\
1.6 & $7 \pm 5$ & 0.16 & $87 \pm 5$ \\
1.0 & $33 \pm 5$ & 0.08 & $99 \pm 1$ \\
\hline
\end{tabular}




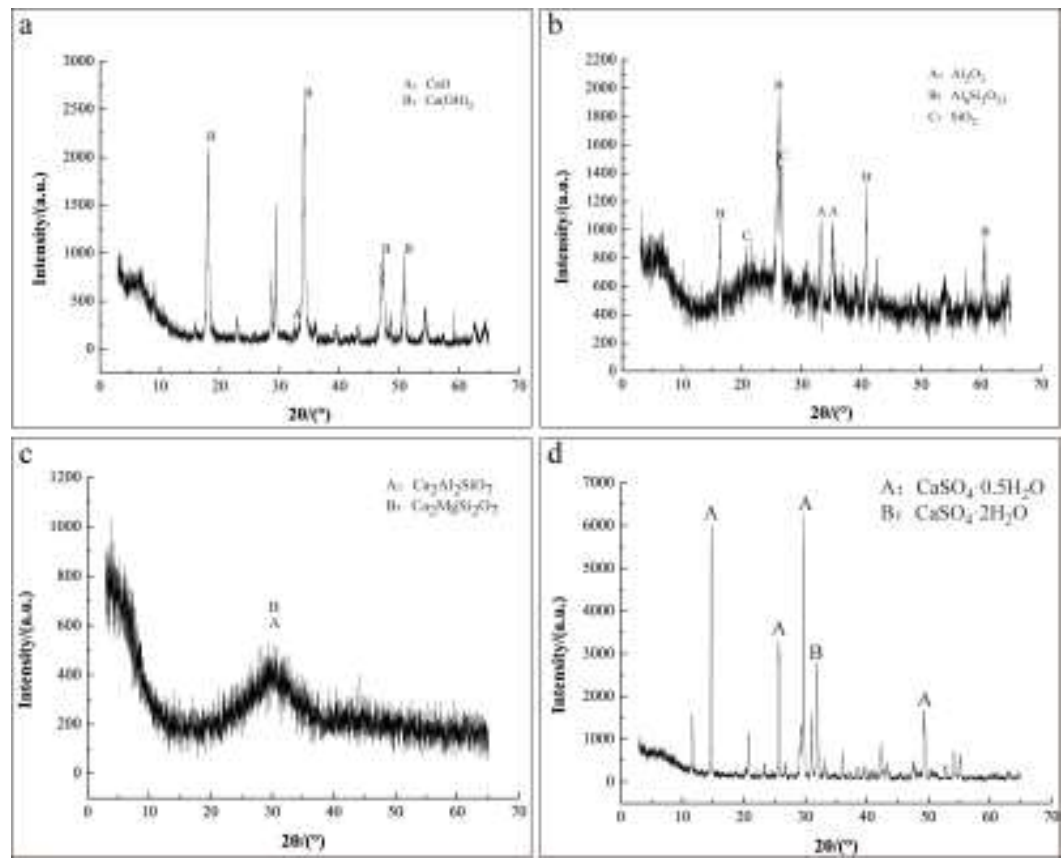

Fig. 1. XRD diffractogram of raw materials (a: CS; b: FA; c: BFS; d: FGD gypsum).

\section{B. Sample preparation}

In this study, the influencing stimulators are: $\mathrm{Na}_{2} \mathrm{SO}_{4}(\mathrm{~A})$, $\mathrm{Na}_{2} \mathrm{SiO}_{3}(\mathrm{~B}), \mathrm{CaCl}_{2}$ (C) and $\mathrm{NaOH}(\mathrm{D})$, with levels as listed in Table 3. The CS, stimulants, FA, FGD gypsum, BFS and superplasticizer were mixed to form composite cementitious materials according to the Table 4 .

Materials were weighed using an electronic balance (accuracy $\pm 0.01 \mathrm{~g}$ ) in accordance with the material ratios given in Table 4; the ratio of cementitious material: sand : water was 2: 8: 1 . The materials were mixed evenly, placed into a mixer, and automatically mixed through the addition of water. Molding followed immediately, and the samples were numbered.

The samples were cured at a temperature of $20 \pm 2{ }^{\circ} \mathrm{C}$ and relative humidity of no less than $50 \%$ for $24 \mathrm{~h}$, after which they were removed from their molds. The samples were subjected to further curing in a curing chamber at $20 \pm 2{ }^{\circ} \mathrm{C}$ and relative humidity greater than $95 \%$. After the specified ages were reached, the $7 \mathrm{~d}$ and $28 \mathrm{~d}$ strengths of the samples were tested.

TABLE 3. AMOUNTS OF STIMULATOR USED FOR THE VARIOUS LEVELS OF ORTHOGONAL TESTING.

\begin{tabular}{|c|c|c|c|c|c|c|c|c|}
\hline \multirow{2}{*}{ Levels } & \multicolumn{8}{|c|}{ Stimulator } \\
\hline & $A$ & $\mathrm{Na}_{2} \mathrm{SO}_{4}(\mathrm{~g})$ & $B$ & $\mathrm{Na}_{2} \mathrm{SiO}_{3}(\mathrm{~g})$ & $C$ & $\mathrm{CaCl}_{2}(\mathrm{~g})$ & $D$ & $\mathrm{NaOH}(\mathrm{g})$ \\
\hline 1 & & 0.6 & & 0.6 & & 0 & & 0 \\
\hline 2 & & 0.9 & & 0.9 & & 1 & & 1.5 \\
\hline 3 & & 1.2 & & 1.2 & & 2 & & 3 \\
\hline 4 & & 1.5 & & 1.5 & & 3 & & 4.5 \\
\hline
\end{tabular}

TABLE 4. PROPORTIONS USED DURING ORTHOGONAL TESTING.

\begin{tabular}{|c|c|c|c|c|c|c|c|c|c|}
\hline \multirow[b]{2}{*}{ No. } & \multicolumn{9}{|c|}{ Raw materials } \\
\hline & $\mathrm{Na}_{2} \mathrm{SO}_{4}(\mathrm{~g})$ & $\mathrm{Na}_{2} \mathrm{SiO}_{3}(\mathrm{~g})$ & $\underset{(\mathrm{g})}{\mathrm{CaCl}_{2}}$ & $\mathrm{NaOH}(\mathrm{g})$ & $\begin{array}{l}F A \\
(g)\end{array}$ & $\begin{array}{c}B F S \\
(g)\end{array}$ & $\begin{array}{c}F G D \\
\text { gypsum (g) }\end{array}$ & $C S(g)$ & Superplasticizer(g) \\
\hline 1 & 0.6 & 0.6 & 0 & 0 & 100 & 27 & 10 & 18 & 0.5 \\
\hline 2 & 0.6 & 0.9 & 1 & 1.5 & 100 & 27 & 10 & 18 & 0.5 \\
\hline 3 & 0.6 & 1.2 & 2 & 3 & 100 & 27 & 10 & 18 & 0.5 \\
\hline 4 & 0.6 & 1.5 & 3 & 4.5 & 100 & 27 & 10 & 18 & 0.5 \\
\hline 5 & 0.9 & 0.6 & 1 & 3 & 100 & 27 & 10 & 18 & 0.5 \\
\hline 6 & 0.9 & 0.9 & 0 & 4.5 & 100 & 27 & 10 & 18 & 0.5 \\
\hline 7 & 0.9 & 1.2 & 3 & 0 & 100 & 27 & 10 & 18 & 0.5 \\
\hline 8 & 0.9 & 1.5 & 2 & 1.5 & 100 & 27 & 10 & 18 & 0.5 \\
\hline 9 & 1.2 & 0.6 & 2 & 4.5 & 100 & 27 & 10 & 18 & 0.5 \\
\hline 10 & 1.2 & 0.9 & 3 & 3 & 100 & 27 & 10 & 18 & 0.5 \\
\hline 11 & 1.2 & 1.2 & 0 & 1.5 & 100 & 27 & 10 & 18 & 0.5 \\
\hline 12 & 1.2 & 1.5 & 1 & 0 & 100 & 27 & 10 & 18 & 0.5 \\
\hline 13 & 1.5 & 0.6 & 3 & 1.5 & 100 & 27 & 10 & 18 & 0.5 \\
\hline 14 & 1.5 & 0.9 & 2 & 0 & 100 & 27 & 10 & 18 & 0.5 \\
\hline 15 & 1.5 & 1.2 & 1 & 4.5 & 100 & 27 & 10 & 18 & 0.5 \\
\hline 16 & 1.5 & 1.5 & 0 & 3 & 100 & 27 & 10 & 18 & 0.5 \\
\hline
\end{tabular}




\section{Methods}

Setting times

The setting times of the cementitious materials were determined using Vicat's apparatus, in accordance with SRPS EN 196-3 (2007) (in compliance with the European EN 196-3 standard).

\section{Consistency}

The consistency of each cementitious material was determined using a SC-145 mortar consistency tester (Hensgrand, China). The prepared cementitious material was placed in the container. When the cone tip just touched the surface of the material, the cone was allowed to fall freely. The depth value determined from the scale on the cone provides the consistency of the cementitious material. All consistency values are averages of duplicate experiments, and are accurate to $1 \mathrm{~mm}$.

\section{Strength}

Measurements of the compressive and flexural strengths of the cementitious materials were made in accordance with SRPS EN 196-1 (2008) (in compliance with the European EN 196-1standard).

\section{XRD analysis}

Samples cured to the specified ages were surface decarbonized with a knife. Blocks of $2.5 \sim 5 \mathrm{~mm}$ in size were removed from the interiors of these samples and placed into a mixture of ethanol and acetone to prevent hydration. The blocks were dried at $40{ }^{\circ} \mathrm{C}$ for about $48 \mathrm{~h}$, ground into fine powders and analyzed by XRD using a D/Max2400 polycrystalline X-ray diffractometer (Rigaku, Japan).

\section{SEM analysis}

Interior-sampled 2.5 5mm blocks, prepared as described in 2.3.4 (above), were placed in a vacuum drying tube at $740 \mathrm{mmHg}$ and a temperature of $60{ }^{\circ} \mathrm{C}$, and dried to constant weight. The blocks were then gold plated under vacuum and cross-sectional morphologies were examined by SEM using a JSM-6380LV scanning electron microscope (JEOL, Japan).

\section{EXPERIMENTAL}

\section{A. Experimental results and orthogonal analysis}

The orthogonal test results are listed in Table 5 and show that different combinations of stimulants affect the strengths of the cementitious materials more than their consistencies and setting times. The $7 \mathrm{~d}$ and $28 \mathrm{~d}$ strengths of test block group 6, which used stimulants in a 1: 1: 0: 5 mass ratios of $\mathrm{Na}_{2} \mathrm{SO}_{4}: \mathrm{Na}_{2} \mathrm{SiO}_{3}: \mathrm{CaCl}_{2}: \mathrm{NaOH}$, were the highest. From the range analysis data in Fig. 2, the influence of each factor on the consistencies of the cementitious materials follows the order: A> B> C> D, which indicates that the $\mathrm{Na}_{2} \mathrm{SO}_{4}$ content has the greatest impact on consistency. The influence of each factor on the initial setting times of the cementitious materials follows the order: D> B> C> A, which means that the $\mathrm{NaOH}$ content has the greatest impact. From the variance analysis data presented in Table 6 , the $F_{j}$ values for $\mathrm{Na}_{2} \mathrm{SO}_{4}, \mathrm{Na}_{2} \mathrm{SiO}_{3}, \mathrm{CaCl}_{2}$ and $\mathrm{NaOH}$ are less than the respective $\mathrm{F}$ values. Given that the null hypothesis is rejected at a specified test level of $5 \%$, we conclude that these stimulants have no significant influence on the consistencies and initial setting times of these cementitious material.
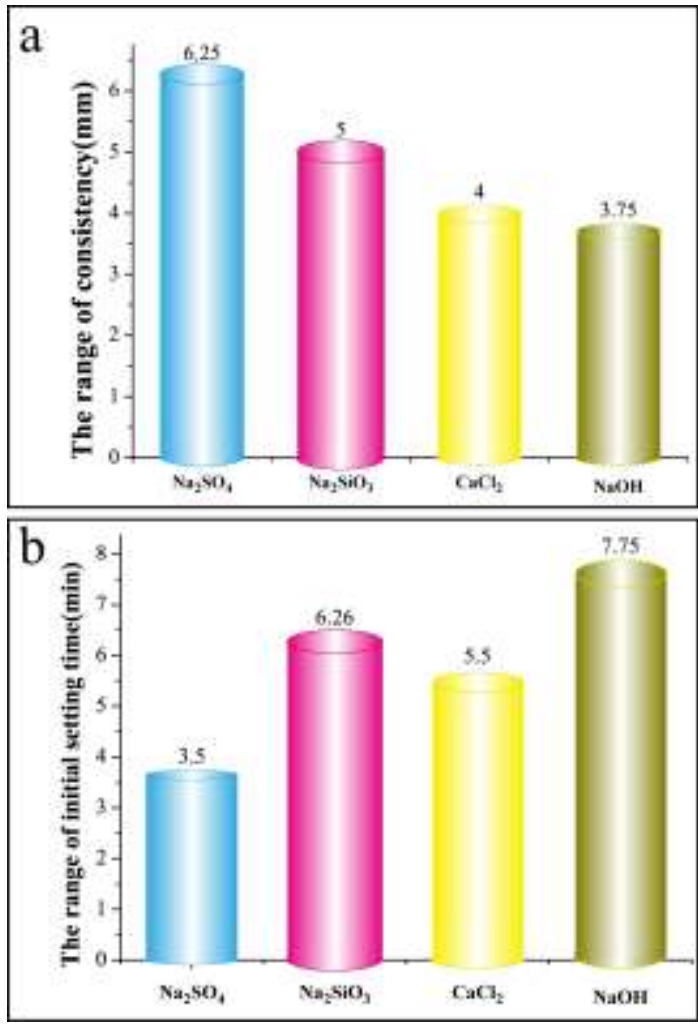

Fig. 2. The range (a: the consistency; b: the initial setting time).

The range analysis data are given in Fig. 3 and show that the influence of each factor on the $7 \mathrm{~d}$ strengths of the cementitious materials follows the order: $\mathrm{D}>\mathrm{C}>\mathrm{A}>\mathrm{B}$. From the variance data in Table $6, \mathrm{~F}_{\mathrm{j}(\mathrm{NaOH})}>\mathrm{F}, \mathrm{F}_{\mathrm{j}(\mathrm{CaCl} 2)}>\mathrm{F}$ for the $7 \mathrm{~d}$ strengths, which implies that the $\mathrm{NaOH}$ content has the greatest influence on the $7 \mathrm{~d}$ strengths of these materials, followed by the $\mathrm{CaCl}_{2}$ content. The strengths of the cementitious materials increase with increasing $\mathrm{NaOH}$ content, and decrease with increasing $\mathrm{CaCl}_{2}$ content. This is the result of the addition of $\mathrm{NaOH}$ to the cementitious system; the $\mathrm{OH}^{-}$destroys the acidic membrane at the surface of FA and BFS particles (Fi. 4). The Si-O and Al-O bonds of the acidic membranes are cleaved to form unsaturated bonds [11,18], leading to increases in the degrees of freedom of the silica $\left[\mathrm{SiO}_{4}\right]^{4-}$ and alumina $\left[\mathrm{AlO}_{4}\right]^{4-}$ tetrahedra. The equations for these reactions are: 


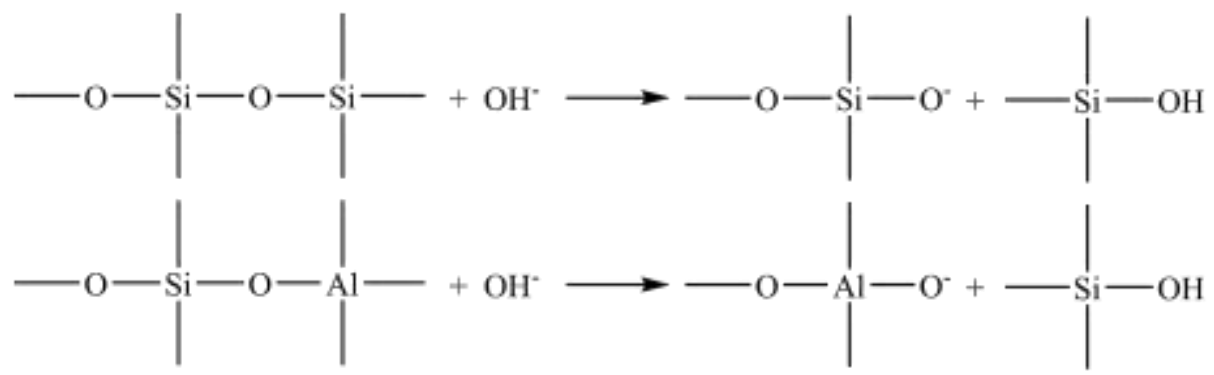

As a consequence, the degree of polymerization of the Si-O-Al network decreases, with unsaturated bonds forming at the surfaces, and free $\mathrm{SiO}_{2}$ and $\mathrm{Al}_{2} \mathrm{O}_{3}$ released. The damage caused by $\mathrm{NaOH}$ to the vitreous surfaces is given by:

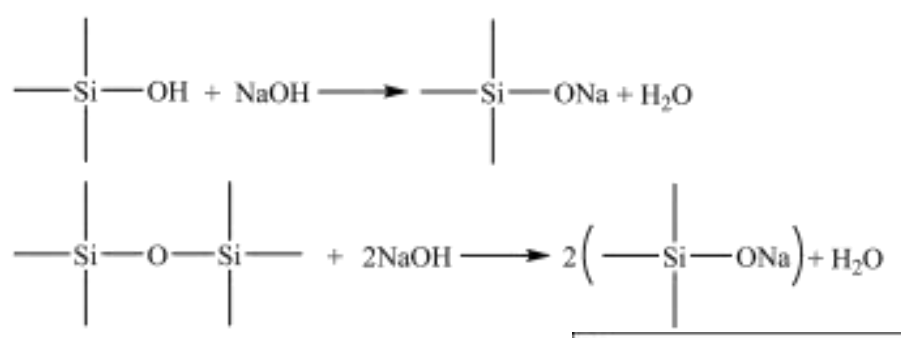

The -Si-ONa produced in the above reactions is soluble in water; subsequent exchange of $\mathrm{Ca}^{2+}$ for $\mathrm{Na}^{+}$leads to the $\mathrm{C}-\mathrm{S}-\mathrm{H}$. Due to the depletion of $\mathrm{Ca}^{2+}$, the $\mathrm{Ca}(\mathrm{OH})_{2}$ produced by the CS and water continues to provide $\mathrm{Ca}^{2+}$ to replace $\mathrm{Na}^{+}$, and the above process continues through a positive cycle. Consequently, the more $\mathrm{NaOH}$ added, the greaterthe activating effect it has on FA and BFS.

When $\mathrm{CaCl}_{2}$ is added to the cementitious system the concentration of $\mathrm{Ca}^{2+}$ increases, inhibiting the dissociation of $\mathrm{Ca}(\mathrm{OH})_{2}$ in the calcium CS and correspondingly reducing the concentration of $\mathrm{OH}^{-}$in the system. Free $\mathrm{Cl}^{-}$, from $\mathrm{CaCl}_{2}$, is strongly penetrating and passes through the hydration shells of the FA and BFS particles, reacting with the active $\mathrm{Al}_{2} \mathrm{O}_{3}$ in the interiors of the particles to form calcium aluminate hydrate, as described by formula (5).

The calcium aluminate hydrate formed in this manner increases the osmotic pressure across these hydration shells, leading to shell rupture; the hydration products formed in this manner weaken the material and reduce its compactness.

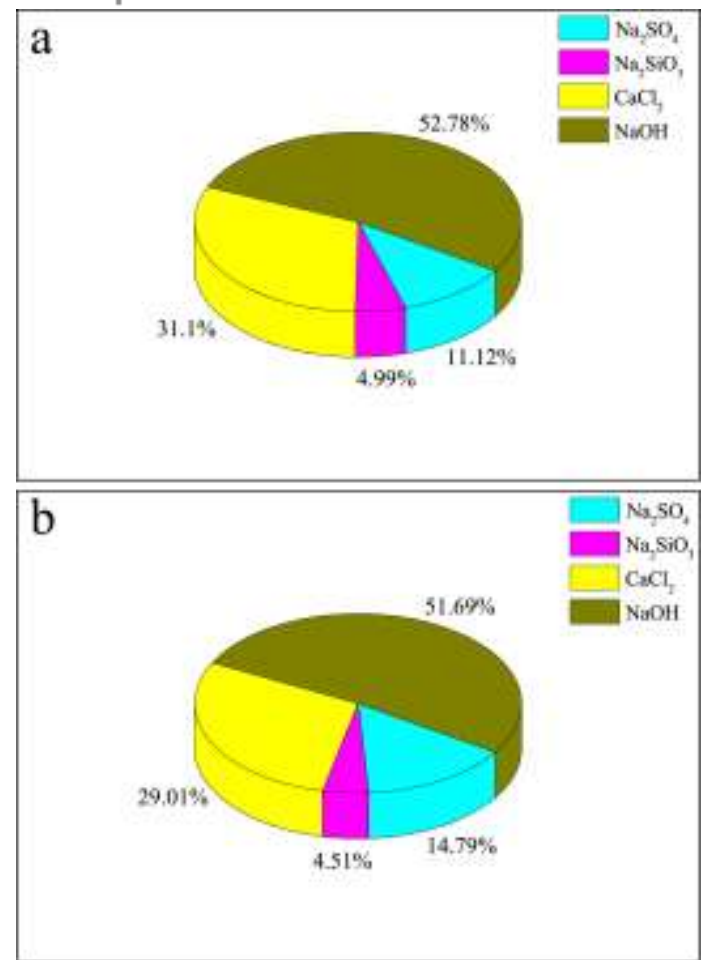

Fig. 3. The range (a: the flexural strength of $7 d$; b: the compressive strength of $7 d)$.

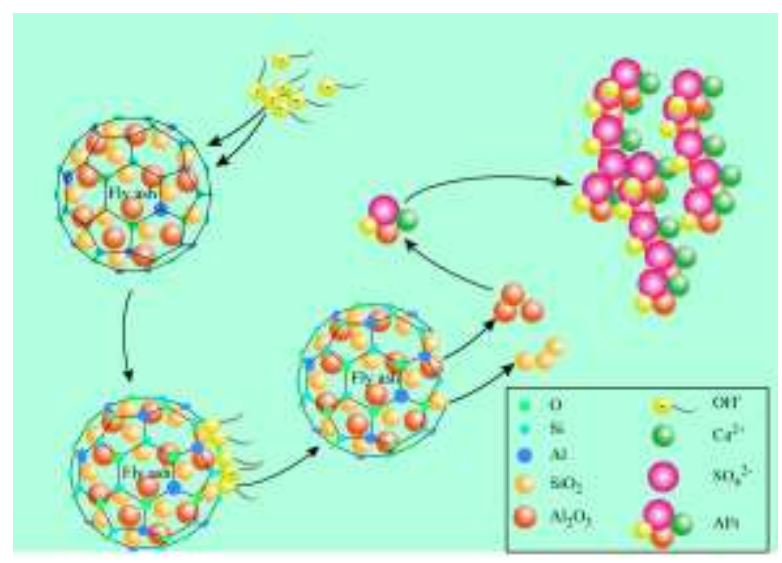

Fig. 4. Hydration mechanism diagram of fly ash. 
From the range analysis data listed in Fig. 5, the influence of each factor on the $28 \mathrm{~d}$ flexural and compressive strengths of the cementitious materials follows the order: $\mathrm{D}>\mathrm{C}>\mathrm{B}>\mathrm{A}$ and $\mathrm{D}>\mathrm{C}>\mathrm{A}>\mathrm{B}$, respectively, indicating that the $\mathrm{NaOH}$ content has the greatest impact, followed by $\mathrm{CaCl}_{2}$. From the variance data in Table $9, \mathrm{~F}_{\mathrm{j}(\mathrm{NaOH})}>\mathrm{F}$ and $\mathrm{F}_{\mathrm{j}(\mathrm{CaCl} 2)}>\mathrm{F}$ for the $28 \mathrm{~d}$ compressive strengths. The null hypothesis is accepted at a specified test level above 5\%, therefore, these influences are significant. The $\mathrm{F}_{\mathrm{j}}$ of $\mathrm{Na}_{2} \mathrm{SO}_{4}$ and $\mathrm{Na}_{2} \mathrm{SiO}_{3}$ are all less than F. Since the null hypothesis is rejected at a specified test level below $5 \%$, we conclude that the effects of these factors are not significant. For the $28 \mathrm{~d}$ flexural strengths, only $\mathrm{F}_{\mathrm{j}(\mathrm{NaOH})}>\mathrm{F}$, indicating that $\mathrm{NaOH}$ has a significant influence on the strengths of the cementitious materials. As the reaction continues, the $\mathrm{Al}_{2} \mathrm{O}_{3}$ and $\mathrm{SiO}_{2}$ released under the action of $\mathrm{NaOH}$ reacts with $\mathrm{Ca}(\mathrm{OH})_{2}$ to form C-S-H and C-A-H in formula (6)-(8).

$$
\begin{aligned}
& \mathrm{Ca}^{2+}+\mathrm{Al}_{2} \mathrm{O}_{3}+\mathrm{Cl}^{-}+\mathrm{OH}^{-} \rightarrow 3 \mathrm{CaO} \cdot \mathrm{Al}_{2} \mathrm{O}_{3} \cdot \mathrm{CaCl}_{2} \cdot 10 \mathrm{H}_{2} \mathrm{O} \\
& \mathrm{SiO}_{2}+\mathrm{Ca}(\mathrm{OH})_{2}+\mathrm{H}_{2} \mathrm{O} \rightarrow \mathrm{CaO} \cdot \mathrm{SiO}_{2} \cdot x \mathrm{H}_{2} \mathrm{O} \\
& \mathrm{Al}_{2} \mathrm{O}_{3}+\mathrm{Ca}(\mathrm{OH})_{2}+\mathrm{H}_{2} \mathrm{O} \rightarrow \mathrm{CaO} \cdot \mathrm{Al}_{2} \mathrm{O}_{3} \cdot x \mathrm{H}_{2} \mathrm{O} \\
& 2 \mathrm{SiO}_{2}+\mathrm{Al}_{2} \mathrm{O}_{3}+\mathrm{Ca}(\mathrm{OH})_{2}+3 \mathrm{H}_{2} \mathrm{O} \rightarrow \mathrm{CaO} \cdot \mathrm{Al}_{2} \mathrm{O}_{3} \cdot 2 \mathrm{SiO}_{2} \cdot 4 \mathrm{H}_{2} \mathrm{O}
\end{aligned}
$$

The C-S-H and C-A-H can bond with each other to fill the pores of the cementitious system. With the passage of time, the strength of the cementitious system increases.
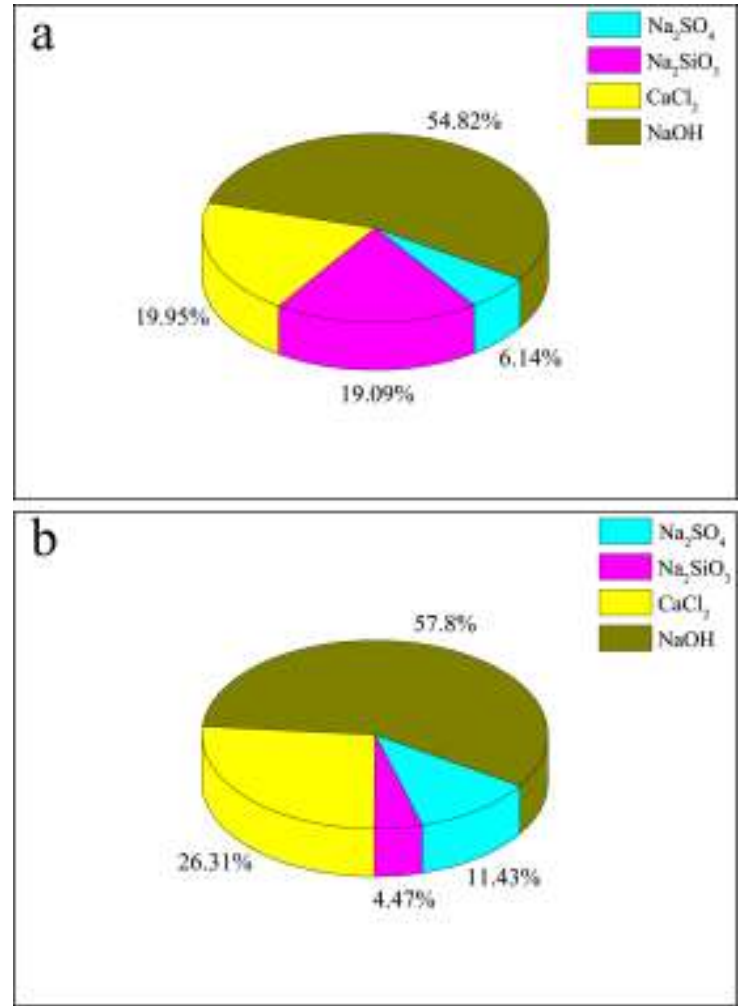

Fig. 5. The range (a: the flexural strength of $28 \mathrm{~d} ; \mathrm{b}$ : the compressive strength of 28d).

\begin{tabular}{|c|c|c|c|c|c|c|c|}
\hline \multirow[b]{2}{*}{ Factor } & \multicolumn{6}{|c|}{$\overline{F_{j}}$} & \multirow[b]{2}{*}{$\mathbf{F}$} \\
\hline & Consistency & $\begin{array}{c}\text { Initial setting } \\
\text { time }\end{array}$ & $\begin{array}{c}\text { Flexural strength at } \\
7 d\end{array}$ & $\begin{array}{c}\text { Compressive strength at } \\
7 \mathrm{~d}\end{array}$ & $\begin{array}{c}\text { Flexural strength at } \\
28 d\end{array}$ & $\begin{array}{c}\text { Compressive strength at } \\
28 d\end{array}$ & \\
\hline $\mathrm{A} \mathrm{Na}_{2} \mathrm{SO}_{4}$ & 1.832 & 0.596 & 2.667 & 4.653 & 0.309 & 2.295 & 9.28 \\
\hline $\mathrm{BNa}_{2} \mathrm{SiO}_{3}$ & 1.061 & 1.989 & 0.556 & 0.4 & 2.985 & 0.337 & 9.28 \\
\hline $\mathrm{CCaCl}_{2}$ & 0.665 & 1.461 & $18.556^{*}$ & $17.76^{*}$ & 4.132 & $11.505 *$ & 9.28 \\
\hline $\mathrm{DNaOH}$ & 0.594 & 2.978 & $60.222 * *$ & $62.987 * *$ & $28 *$ & $63.337 * *$ & 9.28 \\
\hline
\end{tabular}

TABLE 5. ORTHOGONAL TESTING RESULTS.

\begin{tabular}{ccccccc}
\hline & \multirow{2}{*}{$\begin{array}{c}\text { Consistency } \\
\text { No. }\end{array}$} & $\begin{array}{c}\text { Initial } \\
\text { setting }\end{array}$ & \multicolumn{2}{c}{ Strength at 7d (MPa) } & \multicolumn{2}{c}{ Strength at 28d (MPa) } \\
\cline { 3 - 6 } & & time(min) & $\begin{array}{c}\text { Flexural } \\
\text { strength }\end{array}$ & $\begin{array}{c}\text { Compressive } \\
\text { strength }\end{array}$ & $\begin{array}{c}\text { Flexural } \\
\text { strength }\end{array}$ & $\begin{array}{c}\text { Compressive } \\
\text { strength }\end{array}$ \\
\hline 1 & 131 & 286 & 0.284 & 0.563 & 0.68 & 2.033 \\
2 & 127 & 279 & 0.327 & 0.675 & 1.383 & 2.704 \\
3 & 138 & 271 & 0.489 & 1.125 & 1.42 & 3.123 \\
4 & 129 & 276 & 0.556 & 1.254 & 1.503 & 3.273 \\
5 & 132 & 281 & 0.618 & 1.579 & 1.588 & 3.606 \\
6 & 137 & 274 & 0.865 & 2.410 & 1.911 & 3.827 \\
7 & 131 & 282 & 0.184 & 0.338 & 0.594 & 1.638 \\
8 & 129 & 280 & 0.271 & 0.508 & 1.044 & 2.335 \\
9 & 125 & 277 & 0.601 & 1.519 & 1.483 & 3.196 \\
10 & 127 & 284 & 0.280 & 0.510 & 1.361 & 2.519 \\
11 & 130 & 279 & 0.428 & 0.858 & 1.303 & 2.413 \\
12 & 122 & 286 & 0.240 & 0.377 & 0.746 & 2.048 \\
13 & 134 & 280 & 0.182 & 0.267 & 0.624 & 1.915 \\
14 & 127 & 278 & 0.205 & 0.327 & 0.966 & 2.183 \\
15 & 130 & 274 & 0.751 & 1.917 & 1.661 & 3.815 \\
16 & 129 & 289 & 0.720 & 1.619 & 1.486 & 3.212 \\
\hline
\end{tabular}

TABLE 6. VARIANCE ANALYSIS OF THE DATE GIVEN IN TABLE 5.

*Significance level is 0.05 . ** Significance level is 0.01 .

\section{B. XRD and SEM analyses}

Fig. 6 shows the XRD diffraction patterns of sample group 6 at 7d and 28d. The XRD spectrum at 7d exhibits strong diffraction peaks for $\mathrm{Ca}(\mathrm{OH})_{2}$ associated with the cementitious material, quartz $\left(\mathrm{SiO}_{2}\right)$ from the FA, mullite crystals $\left(\mathrm{C}_{5}\left(\mathrm{~S}_{6} \mathrm{O}_{18} \mathrm{H}_{2} \cdot 8 \mathrm{H}_{2} \mathrm{O}\right)\right)$, and the hydration product of AFt. There are also peaks corresponding to small amounts of C-A-H and C-S-H. The AFt formed by hydration, C-A-H and $\mathrm{C}-\mathrm{S}-\mathrm{H}$ interact and bond, giving the cementitious material its initial strength. With the passage of time, at $28 \mathrm{~d}$, $\mathrm{Ca}(\mathrm{OH})_{2}$, quartz and mullite gradually become involved in hydration reactions, as evidenced by the weakening of their diffraction peaks. Correspondingly, the peaks for FAt, C-A$\mathrm{H}$ and $\mathrm{C}-\mathrm{S}-\mathrm{H}$ become stronger. The FAt crystals stack on top of each another to form a 3-D network. The C-A-H and 
C-S-H bond and fill pores [19], resulting in a stronger and more compact cementitious material.

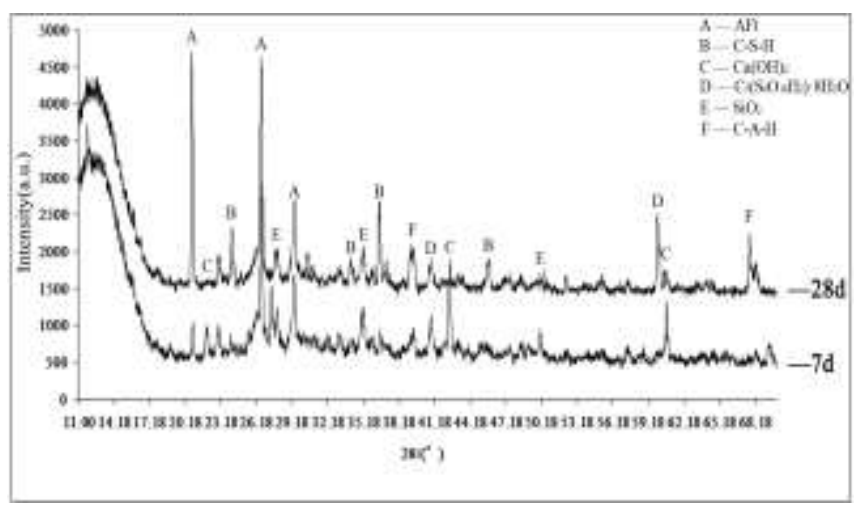

Fig. 6. XRD spectra recorded for sample no. 6 after curing for $7 \mathrm{~d}$ and $28 \mathrm{~d}$.

Fig. 7 shows the SEM images of sample groups 6 and 7 at $7 \mathrm{~d}$ and $28 \mathrm{~d}$. FA particles with bare, smooth surfaces can be seen in Fig. 2(a). The surface appears to be only slightly corroded, with small amounts of active substances having dissolved out of the material and involved in hydration reactions. The hydration products appear to be weakly bonded to their surroundings, and their interiors do not appear to be compact, with large spaces visible. Fig. 2(b) clearly shows that the exposed surfaces of the FA particles are more seriously corroded than those in Fig. 2(a). Large amounts of active substances have dissolved out of the material and have participated in hydration reactions. The hydration products appear bonded to the surfaces of the FA particles, and their interiors seem relatively compact. Sheets of $\mathrm{Ca}(\mathrm{OH})_{2}$ crystals are visible after $7 \mathrm{~d}$ (Fig. 2(c) and (d)), and C-S-H gel, needle-shaped AFt and unhydrated FA particles are present in the hydration products [20,21]. Large amounts of unreacted $\mathrm{Ca}(\mathrm{OH})_{2}$ crystal sheets are evident in Fig. 2(c), and far less needle-shaped AFt is observed in Fig. 2(d), rather the AFt is arranged in a crisscross fashion to form a relatively stable 3-D structure, which greatly enhances the initial strength of the samples. Fig. 2(e) and (f) show that after $28 \mathrm{~d}$ of hydration, the surfaces of the FA particles have become severely corroded. The main hydration products are C-S-H gel sludge and needle-shaped AFt [22]. The degree of hydration appears to be high. Large amounts of hydration product appear to be bonded together to form a 3-D network. After 7d, the pores appear to be filled with hydration products, but the overall structure in Fig. 2(f) appears to be more compact than that depicted in Fig. 2(e) [23-26]. These difference in the microstructures of the cementitious materials clearly resulted in different strengths.
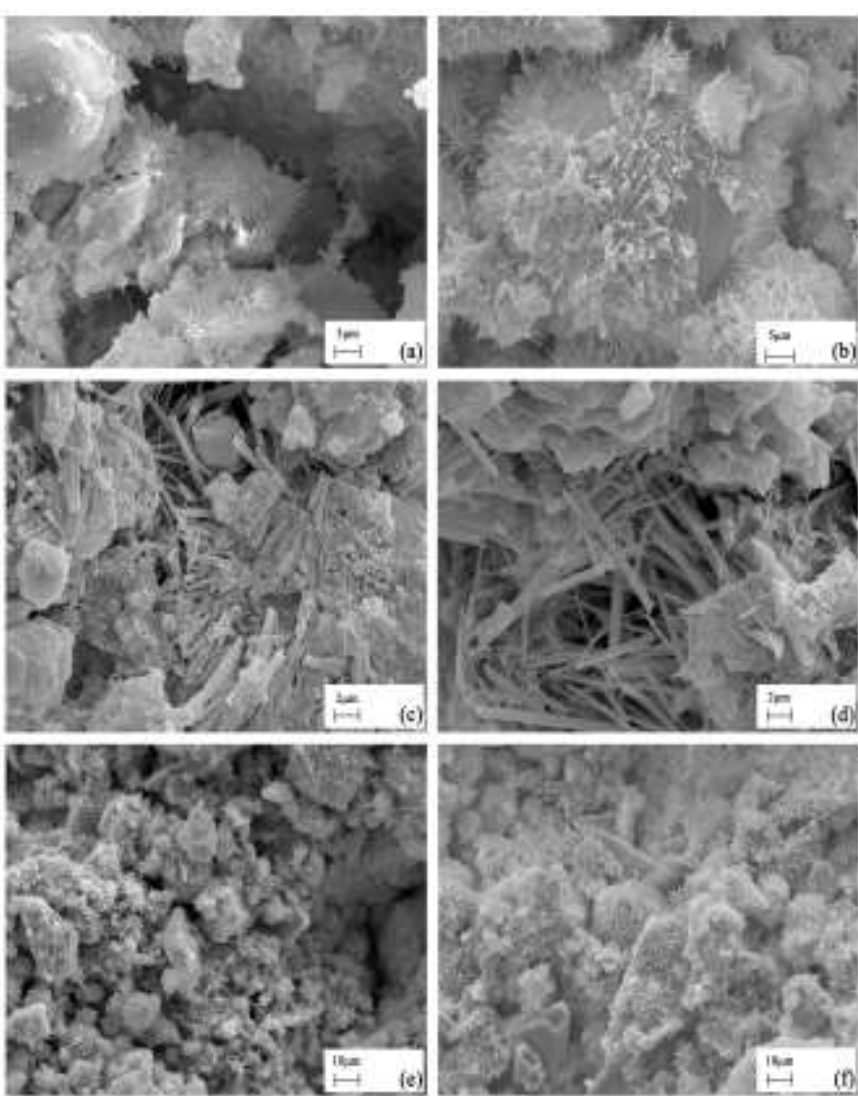

Fig. 7. SEM images of FA powder from samples no. 6 and 7 at different magnifications and ages. Sample no. 7 after: (a) $7 \mathrm{~d}(5000 \times)$, (c) $7 \mathrm{~d}$ (10000x), and (e) $28 \mathrm{~d}(2000 \times)$; sample no. 6 after: (b) $7 \mathrm{~d}(5000 \times)$, (d) $7 \mathrm{~d}$ $(10000 \times)$, and (f) $28 \mathrm{~d}(2000 \times)$.

\section{CONCLUSIONS}

CS is a significant solid waste and its reuse as a mine fill material is an important objective for environmental protection. Consequently, exploring new ways of utilizing CS is important. In order to analyze the effects of different combinations of $\mathrm{NaOH}, \mathrm{CaCl}_{2}, \mathrm{Na}_{2} \mathrm{SO}_{4}$ and $\mathrm{Na}_{2} \mathrm{SiO}_{3}$ on the properties of CS cementitious materials, we studied the influence of these additives on the consistencies, setting times and strengths, through orthogonal testing, and observed the microstructures of the cementitious materials at different ages using XRD and SEM.

In summary, range analyses reveal that the stimulators in this study influence the consistencies of these cementitious materials in the order: $\mathrm{Na}_{2} \mathrm{SO}_{4}>\mathrm{Na}_{2} \mathrm{SiO}_{3}>\mathrm{CaCl}_{2}>\mathrm{NaOH}$, while their influence on initial setting times follows: $\mathrm{NaOH}>$ $\mathrm{Na}_{2} \mathrm{SiO}_{3}>\mathrm{CaCl}_{2}>\mathrm{Na}_{2} \mathrm{SO}_{4}$. Variance analyses indicate that these stimulators do not significantly influence consistenciesor initial setting times of these cementitious materials.

Range and variance analyses reveal that these stimulators influence the strengths of these cementitious materials in the order: $\mathrm{NaOH}>\mathrm{CaCl}_{2}>\mathrm{Na}_{2} \mathrm{SO}_{4}>\mathrm{Na}_{2} \mathrm{SiO}_{3}$. Through the analysis of $7 \mathrm{~d}$ and $28 \mathrm{~d}$ strengths, a 1:1:0:5 mass ratio of $\mathrm{Na}_{2} \mathrm{SO}_{4}: \mathrm{Na}_{2} \mathrm{SiO}_{3}: \mathrm{CaCl}_{2}: \mathrm{NaOH}$ was found to have the best activating effect.

Through XRD and SEM analyses, the hydration products at $7 \mathrm{~d}$ were found to contain small amounts of $\mathrm{AFt}, \mathrm{C}-\mathrm{A}-\mathrm{H}$ and $\mathrm{C}-\mathrm{S}-\mathrm{H}$, and large amounts of unreacted $\mathrm{Ca}(\mathrm{OH})_{2}$. The $\mathrm{AFt}, \mathrm{C}-\mathrm{A}-\mathrm{H}$ and $\mathrm{C}-\mathrm{S}-\mathrm{H}$ content was higher in the hydration products at $28 \mathrm{~d}$, with the amount of $\mathrm{Ca}(\mathrm{OH})_{2}$ significantly 
reduced. The microstructures were consistent with macroscopic strength.

\section{ACKNOWLEDGMENT}

This study was supported by the National Natural Science Foundation of China [grant number 51674038]; Shandong Province Natural Science Foundation [grant number ZR2018JL019]; the China Postdoctoral Science Foundation [grant numbers 2014M560567 and 2015T80730]; the Shandong Province Science and Technology Development Plan [grant number 2017GSF220003]; the State Key Program for Coal Joint Funds of the National Natural Science Foundation of China [grant number U1261205]; Scientific Research Foundation of Shandong University of Science and Technology for Recruited Talents [grant numbers 2017RCJJ010, 2017RCJJ037]; Shandong Province First Class Subject Funding Project [grant number 01AQ05202]; National Natural Science Foundation of China [grant number 51674157]; Taishan Scholar Talent Team Support Plan for Advantaged \& Unique Discipline Areas; the graduate student science and technology innovation project of Shandong University of Science and Technology [grant number SDKDYC170304].

\section{REFERENCES}

11] Chen Weixin, Li Fengyi, Guan Xianhua, et al. "Research on Mining Water-Rich Fly-Ash-Based Filling Material," Advanced Materials Research, vol. 988, pp. 201-206.

[2] Fan Junjie, Cao Deguang, Jing Zhenzi, et al. "Synthesis and Microstructure Analysis of Autoclaved Aerated Concrete with Carbide Slag Addition," Journal of Wuhan University of Technology (Materials Science Edition), vol. 29, pp. 1005-1010.

[3] Wang Yali, Cui Suping, Wang Hui, et al. "Effects of Preparation of Cement Raw Meal with Carbide Slag on the Environment and Equipments," Materials Science Forum, vol. 787, pp. 123-127.

[4] Wang Yali, Dong Shijie, Liu Linlin, et al. "Using Calcium Carbide Slag as one of Calcium-containing Raw Materials to Produce Cement Clinker," Materials Science Forum, pp.171-174.

[5] Li Yingjie, Sun Rongyue, Liu Changtian, et al. " $\mathrm{CO}_{2}$ capture by carbide slag from chlor-alkali plant in calcination/carbonation cycles," International Journal of Greenhouse Gas Control, vol. 9(3), pp. 117123.

[6] Pavithra, P., Srinivasula Reddy, M., Dinakar, Pasla. et al. "A mix design procedure for geopolymer concrete with fly ash," Journal of Cleaner Production, vol. 133, pp. 117-125

[7] Horpibulsuk, Suksun, Rachan, Runglawan, Chinkulkijniwat, Avirut, et al. "Analysis of strength development in cement-stabilized silty clay from microstructural considerations," Construction \& Building Materials, vol. 24(10), pp. 2011-2021.

[8] Suksun Horpibulsuk, Chayakrit Phetchuay, Avirut Chinkulkijniwat. "Soil Stabilization by Calcium Carbide Residue and Fly Ash," Journal of Materials in Civil Engineering, vol. 24(2), pp. 184-193.

[9] Yi Yaolin, Gu Liyang, Liu Songyu, et al. "Carbide slag-activated ground granulated blastfurnace slag for soft clay stabilization," Canadian Geotechnical Journal, vol. 52(5), pp. 656-663.

[10] Hao Chengwei, Deng Min, Mo Liwu, et al. "Surface modification of fly ashes with carbide slag and its effect on compressive strength and autogenous shrinkage of blended cement pastes," Journal of Wuhan University of Technology (Materials Science Edition), vol. 27(6), pp. 1149-1153.

[11] Guo Xiaolu, Shi Huisheng, Chen Liming, et al. "Alkali-activated complex binders from class C fly ash and Ca-containing admixtures," Journal of Hazardous Materials, vol. 173(1-3), pp. 480-486.

[12] Pavel Rovnaník, Bohuslav Řezník, Pavla Rovnaníková. "Blended Alkali-activated Fly Ash / Brick Powder Materials," Procedia Engineering, vol. 151, pp. 108-113.

[13] Nematollahi, Behzad, Sanjayan, Jay. "Effect of different superplasticizers and activator combinations on workability and strength of fly ash based geopolymer," Materials \& Design, vol. 57(5), pp. 667-672.

[14] Criado M., Jiménez, A. Fernández, Palomo A. "Effect of sodium sulfate on the alkali activation of fly ash," Cement \& Concrete Composites, vol. 32(8), pp. 589-594

[15] Yi Yaolin, Li Cheng, Liu Songyu. "Alkali-Activated GroundGranulated Blast Furnace Slag for Stabilization of Marine Soft Clay," Journal of Materials in Civil Engineering, vol. 27(4), doi : 10.1061/(ASCE)MT.1943-5533.0001100.

[16] N. Marjanović, M. Komljenović, Z. Baščarević, et al. "Physicalmechanical and microstructural properties of alkali-activated fly ashblast furnace slag blends," Ceramics International, vol. 41(1), pp. 1421-1435.

[17] Zhang Yi, Wang Xintang, Zhou Ming, et al. "Orthogonal Test of Characteristics of Complex Cememting Material of FGD Gypsum-Fly Ash," Advanced Materials Research, vol. 250-253, pp. 460-463.

[18] Fernando S. Fonsecaa, Robert C. Godfreyb, Kurt Siggardc. "Compressive strength of masonry grout containing high amounts of class F fly ash and ground granulated blast furnace slag," Construction \& Building Materials, vol. 94, pp. 719-727.

[19] N. Marjanović, M. Komljenović, Z. Baščarević, et al. Petrović. "Physical-mechanical and microstructural properties of alkaliactivated fly ash-blast furnace slag blends," Ceramics International, vol. 41(1), pp. 1421-1435.

[20] Chen Guanyu, Huang Weisheng. "Investigation on Blending CFB Ash with Blast Furnace Slag as Replacement for Portland Cement Used in Concrete Binders," Advanced Materials Research, vol. 723, pp. 623-629.

[21] Ma Bing, Li Xuerun, Mao Yuyi, et al. "Synthesis and characterization of high belite sulfoaluminate cement through rich alumina fly ash and desulfurization gypsum," Ceramics-Silikáty, vol. 57(1), pp. 7-13.

[22] Pastor, José L., Ortega, J. Marcos, Flor, María, et al. "Microstructure and durability of fly ash cement grouts for micropiles," Construction \& Building Materials, vol. 117, pp. 47-57.

[23] Qin Honggen, Liu Xiaoqin, Li Gang. "Preparation and properties of desulfurization gypsum-slag hydraulic cementitious materials," Procedia Engineering, vol. 27, pp. 244-252.

[24] Zhang Qian, Hu Xiangming and Wu Mingyue, et al. "Effects of different catalysts on the structure and properties of polyurethane/water glass grouting materials," Journal of Applied Polymer Science, vol. 135. http://dx.doi.org/10.1002/app.46460.

[25] Hu Zunxiang, Hu Xiangming, Cheng WeiMin, et al. "Performance optimization of one-component polyurethane healing agent for selfhealing concrete," Construction and Building Materials, vol. 179, pp. 151-159.

[26] Wu Mingyue, $\mathrm{Hu}$ Xiangming, Qian Zhang, et al. "Orthogonal Experimental Studies on Preparation of Mine-Filling Materials from Carbide Slag, Granulated Blast-Furnace Slag, Fly Ash, and Flue-Gas Desulphurisation Gypsum," Advances in Materials Science and Engineering, vol. 2018, pp. 1-12. 